\title{
To ansøgninger fra den unge Grundtvig
}

\author{
Ved Knud Eyvin Bugge.
}

Den igangværende registrering af Gr.s efterladte papirer tilsigter - i hvert tilfælde i første omgang - kun en behandling af det arkivmateriale, der beror på Det Kgl. Bibliotek. En eftersøgning af Gr.papirer, der andetsted kan være bevaret, er forbundet med store vanskeligheder, selv når man retter opmærksomheden imod de offentlige arkiver. Det viser sig nemlig, at Gr.papirer undertiden dér kan være indlagt som bilag til verserende sager og derfor ikke er registreret under hans navn. Sådanne aktstykker vil derfor kun kunne opspores i de tilfælde, hvor man fra anden side véd, at Gr. har været engageret $\mathrm{i}$ den og den »sag «.

I det følgende skal to fund i Rigsarkivet meddeles GrundtvigStudiers læsere. Det er dels Gr.s eksamens-petitum fra september I 803 og hans ansøgning om alumneplads på Valkendorfs Kollegium fra maj ı 8o8. Inden aktstykkerne aftrykkes, vil det være på sin plads at sige et par ord om selve manuskripterne; ansøgningernes indhold giver derimod ikke anledning til kommentar.

Gr.s eksamens-petitum findes i Universitetets arkiv, Nr. I I 65 (Theologisk embedseksamen, Petita). I Gr.s samtidige dagbog findes dokumentet omtalt $i$ en notits fra 8/9-I8o3, hvor det hedder: »Jeg udgav I4 sk. paa en Vinkelder og I R til mit Petitum « (Fasc. 496; udateret men umiddelbart før en optegnelse af $9 / 9$ i en række regelmæssigt fortløbende, daglige, notater). Hvorfor Gr. har måttet betale I $R$. for sit petitum, vides ikke. De officielle bestemmelser vedr. theologisk embedseksamen på Gr.s tid indeholder intet krav om en afgift forbundet med indgivelse af petitum (Se Universitetsfundatsen af 7/5-I 788 kap. IV $\S 3$, trykt i Chronologisk Register over de kongelige Forordninger etc. ved J. H. Schou X ( I 793) samt Matzen: Kjøbenhavns Universitets Retshistorie II I6g f). Da håndskriften kun meget svagt minder om den, man kender fra Gr.s dagbogsoptegnelser fra samme tid, melder det spørgsmål sig, om 
Gr. skulde have betalt en anden for at skrive sit petitum for sig. Denne løsning er dog utilfredsstillende, da man véd, at Gr. var fattig som student og næppe vilde have brugt I $R$. på at få udfærdiget et dokument, han som stiv latiner med lethed selv kunde forfatte. Tilbage står da to muligheder: I) Enten foreligger der her et forsøg på skønskrift, eller 2) Gr. har betalt en anden for at renskrive manuskriptet. I det første tilfælde kan udgiften da evt. forklares som betaling - evt. til et underordnet medlem af universitetets personale - for at befordre ansøgningen videre til rette sted. Hvorledes dette end forholder sig, har dokumentet krav på at blive kendt som det petitum, Gr. indsendte i forbindelse med sin embedseksamen.

Gr.s ansøgning om alumneplads på Valkendorfs Kollegium er indlagt blandt Niels Treschows Circularia fra 1807-08, kapsel nr. 3, Universitetets arkiv. Rønning, der har citeret en enkelt passus fra ansøgningen (II, I s. 6o), opgiver som kilde »Konsistoriums arkiv«. Med mindre denne angivelse kun skal dække selve udnævnelsen, er den mindre nøjagtig. Det lykkedes først at opspore dokumentet ved blandt Rønnings papirer at finde en henvisning til Treschows rektoratsarkiv. Ansøgningen er, som det vil ses, udateret. Den må dog være skrevet mellem d. I/5 (Datoen for Gr.s ankomst til København, jf. udtrykkene »ilede hid. Jeg er her ...« samt Steen Johansens oplysning i Gr. Stud. I96o, 6o) og 15/5-18o8, som er datoen for eforens, prof. Fr. Münters følgeskrivelse til konsistorium.

Perillustrissimi doctissimique

S:S Theologiæ Professores!

Hisce qvi litteris sui Theologicis profectus rationem redditurus, Vobis, apprime Venerandi! Vestra Clementia fretus sese commendare est ausus, ortum debet Johanni Grundtvig, sacrorum oraculorum, apud Udbyenses \& Ørslevienses in Sjælandia interpreti, cujus in æde pastorali natus Ao I 783 annos egit pueriles.

Privatos inter parietes a Dno Laurentio Feld scientiarum fundamentis imbutus, scholam petii Arhusinam, cujus cum scabella per biennium pres-
Vidtberømte og højlærde Professorer i den hellige Theologi!

Undertegnede, som står i begreb med at aflægge regnskab for sin fremgang i de theologiske fag, tillader sig herved i tillid til eders mildhed at anbefale sig til eders Højærværdigheder. Jeg er søn af Johan Grundtvig, præst i Udby og Ørslev i Sjælland, i hvis præstegård jeg blev født i året I 783 , og hvor jeg tilbragte mine drengeår.

Mine elementære kundskaber har jeg fået gennem privatundervisning hos Hr. Laurits Feld; derpå søgte jeg skolen i Århus, og da jeg igennem to 
sissem, Ao I 800 mense Octobris sum dimissus; meque, Examen Artium laudabiliter absolventem, hujus Academiæ Senatus Civitate donavit. Ao I80 I mense Aprilis ex Philosophico Examine Caractere Laudabili reportato, anno eodem in finem vergente Philologico me subjeci Examini, unde haudillaudabilis evasi.

Hisce ita peractis, ad Theologix studium me statim accinxi, Vestrisqve, Celeberrimi! freqvens vacavi prælectionibus, quibus notitias, qvas mihi parare licuit, animo, qvo par est, gratissimo acceptas fero.

Cum ita, Vobis, Doctissimi! Ducibus tum in aliis Theologiam attingentibus scientiis, tum in Libro Psalmorum tertio interpretando explicandoqve omnes intendens nervos, pro virili fecerim progressus, submisse precor ut Vos, summe Venerandi! me, Examini Theologico jam instanti admissum, Vestro adornetis favore.

Tantorum Nominum

Nicolaus Fredericus Severinus

Grundtvig

Dabam Hafniæ d. 8vo Septembris I803. år havde slidt dens bænke, blev jeg dimitteret i året $\mathrm{I} 800 \mathrm{i}$ oktober måned; da jeg havde bestået examen artium med karakteren laud, skænkede dette universitets konsistorium mig borgerskab. Efter at jeg i året 180 I i april måned havde bestået filosofisk eksamen med karakteren laud, underkastede jeg mig - da det samme år gik på hæld - den filologiske eksamen med udfaldet haud illaudabilis.

Efter at være kommet så vidt, gav jeg mig straks i lag med studiet af theologi. Ofte har jeg bivånet eders forelæsninger, Højærværdige! og de dér indhøstede kundskaber tager jeg med mig med behørig taknemmelighed.

Under eders vejledning, Højlærde! har jeg således anspændt alle mine kræfter og efter evne gjort fremskridt dels indenfor andre theologien vedkommende fag og dels ved at oversætte og fortolke Psalmernes tredie bog, hvorfor jeg ærbødigst anmoder eders Højærværdigheder om gunstig tilladelse til at indstille mig til den nu forestående theologiske eksamen.

I dyb ærbødighed overfor så fremragende mænd,

Nicolaj Frederik Severin Grundtvig Skrevet i København d. 8de September 1803 . 


\section{Erbodigst Promemoria!}

Haderlige Mand

\section{Det Høje Konsistoriums Medlemmer!}

I Aaret I803 endte jeg det befalede Kursus ved Universitetet, da jeg ved theologisk Prøve erklæredes Laudabilis.

Følende ret dybt, at al den Studering, der kan befales, er et Intet, naar den ej vækker levende Lyst hos Individet til at udvikle sin aandige Kraft og prøve den paa de Videnskabens Dele, hvortil Han finder Drift og troer at finde Anlæg, nærede jeg ej heller dengang noget Ønske, uden det, at kunne med den større Frihed fordoble mit Arbejde.

Det gamle Nords Historie og Gudelære havde fra den tidlige Barndom sysselsat min Videlyst og Fantasi. De bleve da ogsaa især Genstandene for den modnere Alders Flid og Tænkning. Da disse Fag, som bekendt, ere blandt dem, som ej engang den Bemidlede kan, borte fra Bogsamlingerne dyrke med megen Held, maatte jeg, som Fattig, dobbelt føle Nødvendigheden af, enten at blive i Hovedstaden, eller næsten at opgive den eneste Syssel, der fuldelig stemte med min særegne Trang. Lykken, som aldrig var mig blid, tillod mig intet Valg, og jeg gjorde, ej hvad jeg/ vilde, men hvad jeg maatte.

Næsten fem Aar ere nu henrundne, og ethvert Skridt jeg i den Tid gjorde til nøjere at beskue mine valgte Genstande, lode mig kun tydeligere føle, hvormeget jeg manglede den nødvendige Indsigt. Trøstesløs over at Sammes Erhvervelse var aldeles umulig i min Stilling, vovede jeg endnu engang at trodse Skebnen, og ilede hid.

Jeg er her, og føler mig lykkelig i Videnskabernes Helligdomme; men jeg kan ikke dølge for mig selv den ængstelige Vished, at naar ingen Hjelp kommer udenfra, da maa jeg, længe før jeg nærmer mig mit Maal, kaste mig i en Stilling, der end mindre harmonerer med mine motiverede Ønsker. Derfor anseer jeg det som en Pligt at gaa enhver lovlig Vej, der kunde føre til en skønnere Bane.

Derfor er det, jeg vover at henvende mig til de hæderlige Videnskabsmænd, som udgøre det høje Konsistorium, endskønt jeg er aldeles ukendt af de Fleste. Jeg vover i Almindelighed at udbede mig Deres Godhed, naar Stipendier hvortil jeg kunde ansees værdig, uddeles, og i Særdeleshed beder jeg om den ledigværende Plads paa Valkendorphs Kollegium, hvorved mit Ophold her vilde meget lettes.

Med sand Høiagtelse

ærbødigst

Nik. Fred. Sev. Grundtvig. 